\section{SOI: $1.1 /$ TAS DOI: $10.15863 / \mathrm{TAS}$ International Scientific Journal Theoretical \& Applied Science}

\author{
p-ISSN: 2308-4944 (print) e-ISSN: 2409-0085 (online)
}

Year: 2018 Issue: 09 Volume: 65

Published: $24.09 .2018 \quad$ http://T-Science.org
Muhammad Ayub

Dr., Assistant Professor Gastroenterology in DHQ

Teaching Hospital Gujranwala Medical College Gujranwala, Pakistan mnaich@hotmail.com

Shehryar Noor

Dr., consultant general surgeon in Khyber Teaching Hospital Peshawar, Pakistan shehryar.md@gmail.com

Zahra Aleem

Dr., Doctor in Jinnah Hospital Lahore,

Pakistan

za_al@live.com

\title{
DERRANGED COAGULATION PROFILE \& RISK OF GASTROINTESTINAL BLEEDING
}

\begin{abstract}
Objective: Purpose of conducting this study was to determine risk of gastrointestinal bleeding due to abnormal coagulation profile in patients with chronic liver disease.

Study design and setting: This study was done in in DHQ Teaching Hospital Gujranwal Medical College Gujranwala, Pakistan.

Study duration: This study was started in January 2018 and completed in July 2018 consisted on period of 7 months duration

Patients and Methods: Patients with chronic liver disease with deranged coagulation profile and signs and symptoms of gastrointestinal bleeding presenting to outpatient door or emergency ward of study institution during study period were selected. Proper history taken and physical examination was done followed by necessary investigations such as USG abdomen, clotting profile (PT, APTT, INR), CBC with platelet count, LFTs, RFTs and stool culture for occult blood or malena. Unstable patients presented in emergency ward well given initial resuscitation and bleeding were stopped with conservative management successfully. Only those cases were selected having No chronic disease other than CLD, Not taking any anticoagulant for any disease and no family history of bleeding disorder. A performa was designed containing necessary questions like age, duration of disease, signs and symptoms of CLD such as ascites, hematemesis, per rectal bleeding, malena etc. Data was analyzed on Microsoft office and statistical software. Relative risk was calculated with $95 \%$ confidence interval.

Results: Total 280 cases reported with chronic liver disease out of which 150 cases were having gastrointestinal bleeding having history of malena and hematemesis. There were $76.7 \%$ cases with prolonged prothrombin time. In $88.6 \%$ cases APTT was prolonged. $88.6 \%$ were having low platelet count less than $1.5 \times 105$. There were $58.7 \%$ male and $41.3 \%$ female cases. Age of patients was in range of 30-75 years with mean age of 50.4 years $\pm 14.6 S D$. Confidence interval was $95 \%$, relative risk 1.55 and P value was less than 0.05 . In $70 \%$ cases hematemesis or malena was present. In $42.7 \%$ only hematemesis, $63.3 \%$ having malena and in $46.6 \%$ both were present. $31.3 \%$ cases had encephalopathy, $48.7 \%$ fever, $60.7 \%$ jaundice, $25.3 \%$ hepatomegaly, $69.3 \%$ spleenomegaly, $56.7 \%$ ascites and $8 \%$ cases had spider angioma.

Conclusion: Chronic liver disease is most prevalent disease in Pakistan in which coagulation profile is deranged with prolonged PT, APTT and decreased platelet count. Gastrointestinal hemorrhage is common presentation in CLD.

Key words: Complications of CLD, Derrange coagulation profile, gastrointestinal bleeding.

Language: English

Citation: Ayub M, Noor S, Aleem Z (2018) DERRANGED COAGULATION PROFILE \& RISK OF GASTROINTESTINAL BLEEDING. ISJ Theoretical \& Applied Science, 09 (65): 106-111.

Soi: http://s-o-i.org/1.1/TAS-09-65-16 Doi: crostef https://dx.doi.org/10.15863/TAS.2018.09.65.16

\section{INTRODUCTION}

Chronic liver disease has very high incidence in Pakistan and other asian countries as well. In this disease liver functions are compromised. Liver is very important organ of body related to metabolism, glucose production, protein synthesis and

detoxification of toxic metabolites. ${ }^{1}$ Most common cause of lchronic liver disease is viral hepatitis due to $\mathrm{HCV}$ and HBV. Other viruses like HAV and HEV also causes hepatitis but their incidence is very low in our country and usually don't cause chronic liver disease. $^{2}$ Other cause of CLD is Willson disease.
\end{abstract}


Signs and symptoms in this disease are hematemesis, per rectal bleeding, black stools, abdominal distension due to ascites, chronic on and off fever, unexplained weight loss, indigestion, anemia, palmar erythema, Jaundice, hepatomegaly, splenomegaly spider angiomas and encephalopathy. There may be chronic constipation and hemorrhoids. ${ }^{3}$ Chronic liver disease occurs many years after infection with HBV or HCV so cases with CLD are usually old age. Liver functions are gradually lost. Very important function of liver is to maintain portal pressure and in case of liver failure in CLD liver cirrhosis occurs causing portal hypertension and complications related to it such as hemorrhoids, gastric or esophageal variceal bleeding and ascites. In this disease protein synthesis is impaired. ${ }^{4}$ Albumin is very important protein synthesized by liver maintaining oncotic pressure intravascularly. Its level is also used to diagnose liver failure and to monitor prognosis of disease and outcome of treatment. Normal value of prothrombin time is $11-13.5$ which is prolonged greater than 14 in liver disease. In severely ill cases its value becomes greater than 45 . Vitamin $\mathrm{K}$ dependent clotting factors 2, 7, 9 and 10 factor synthesis occurs in liver. Liver failure causes impaired vitamin metabolism so decreasing level of clotting factors. Prognostic factors in CLD are blood albumin level, PT and APTT level, platelet count and fibrinogen level. Patients with deranged coagulation profile and low albumin level have worst prognosis. ${ }^{5}$ Medical management includes intravenous albumin transfusion, vit $\mathrm{K}$, sandostatin and intravenous fluids etc. Definite treatment includes liver transplantation, but this option is suitable in surgically fit patients. Patients in old age are not fit for this surgery so they are treated conservatively. Most of the patients are reported in hospitals in advance disease stage as initial signs symptoms of disease are general and easily misdiagnosed or ignored. ${ }^{6}$ Patient considers he is healthy and it is incidentally diagnosed when serum viral markers are checked for any surgery or before donation of blood. Most common cause of viral hepatitis is blood born transmission from infected patients, infected syringes and from mother to child during delivery and from body fluids of infected person.

\section{Patients and Methods}

This is a cross sectional study conducted in a teaching hospital of Pakistan with study duration of seven months. Patients with chronic liver disease with deranged coagulation profile and signs and symptoms of gastrointestinal bleeding presenting to outpatient door or emergency ward of study institution during study period were selected. Proper history taken and physical examination was done followed by necessary investigations such as USG abdomen, clotting profile (PT, APTT, INR), CBC with platelet count, LFTs, RFTs and stool culture for occult blood or malena. All necessary investigations of study cases were done from the laboratory of study institution. Unstable patients presented in emergency ward well given initial resuscitation and bleeding were stopped with conservative management successfully. Only those cases were selected having no chronic disease other than CLD, Not taking any anticoagulant for any disease and no family history of bleeding disorder. Signs and symptoms in this disease are hematemesis, per rectal bleeding, black stools, and abdominal distension due to ascites, chronic on and off fever, unexplained weight loss, indigestion, anemia, palmar erythema, Jaundice, hepatomegaly, splenomegaly spider angiomas and encephalopathy. Patients above 30 years of age were included and those having age less than this were excluded from the study. Patients having hematological diseases like leukemia, lymphomas and aplastic anemia etc were not included in this study. Proper written consent was taken from each and every patient for including their data in study and also from the medical superintendant of the hospital for conducting study. Privacy of patient was maintained. A performa was designed containing necessary questions like age, duration of disease, signs and symptoms of CLD such as ascites, hematemesis, per rectal bleeding, malena etc. Data was analyzed on Microsoft office and statistical software. Relative risk was calculated with $95 \%$ confidence interval.

\section{Results}

Patients presenting in outpatient door and emergency ward due ti signs and symptoms of chronic liver disease were studied. Total 280 cases reported with chronic liver disease out of which 150 cases were having gastrointestinal bleeding having history of malena and hematemesis. There were $76.7 \%$ cases with prolonged prothrombin time. In $88.6 \%$ cases APTT was prolonged. 86(57.3\%) were having low platelet count less than $1.5 \times 10^{5}$, $10(11.6 \%)$ cases had platelet level between one lac to 1.5 lac, 59(68.6\%) cases had platelet range of fifty thousand to one lac and 17(19.7\%) cases had platelet count below fifty thousand. There were $88(58.7 \%)$ male and $62(41.3 \%)$ female cases. Age of patients was in range of 30-75 years with mean age of 50.4 years \pm 14.6 SD. Confidence interval was $95 \%$, relative risk 1.55 and $\mathrm{P}$ value was less than 0.05 . In $105(70 \%)$ cases hematemesis or malena was present. In $64(42.7 \%)$ only hematemesis, 95(63.3\%) having malena and in $70(46.6 \%)$ both were present. $47(31.3 \%)$ cases had encephalopathy,73(48.7\%) fever, $91(60.7 \%)$ jaundice, $38(25.3 \%)$ hepatomegaly, $104(69.3 \%)$ spleenomegaly, $85(56.7 \%)$ ascites and $12(8 \%)$ cases had spider angioma. There were $12(8 \%)$ cases between $30-35$ years, $28(18.7 \%)$ with 


\begin{tabular}{|c|c|c|c|c|c|c|}
\hline \multirow{4}{*}{ Impact Factor: } & ISRA (India) & $=1.344$ & SIS (USA) & $=0.912$ & ICV (Poland) & $=6.630$ \\
\hline & ISI (Dubai, UAF & $=0.829$ & РИНЦ (Russia) & $=0.156$ & PIF (India) & $=1.940$ \\
\hline & GIF (Australia) & $=0.564$ & ESJI (KZ) & $=4.102$ & IBI (India) & $=4.260$ \\
\hline & JIF & $=1.500$ & SJIF (Morocco & $=2.031$ & & \\
\hline
\end{tabular}

age $36-40$ years, $20(13.3 \%)$ between $41-45$ years,

$18(12 \%)$ cases between $41-45$ years, and $25(16.7 \%)$

cases were above 60 years of age.

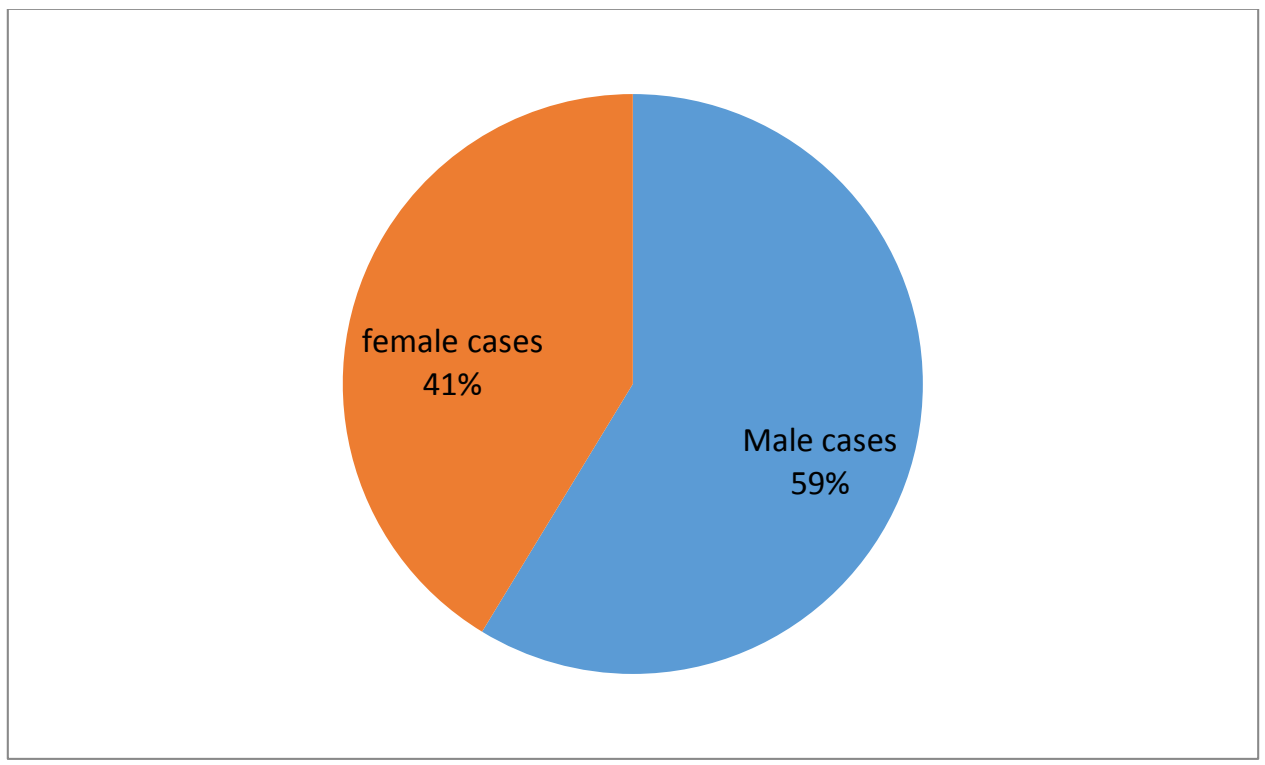

Figure-1 Gender distribution of patients in study group

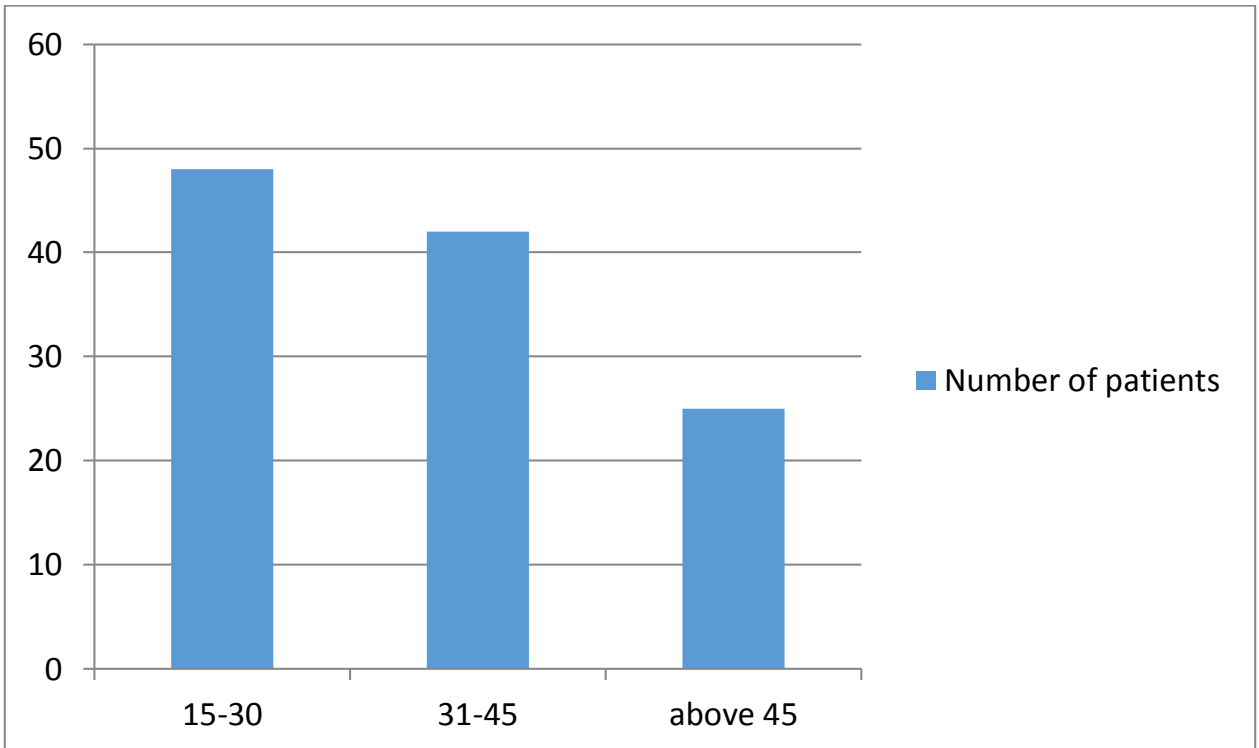

Figure-2 Frequency of patients with prolonged prothrombin time (PT above $35 \mathrm{sec}$ ) 


\begin{tabular}{l|lr|ll|ll} 
& ISRA (India) & $=\mathbf{1 . 3 4 4}$ & SIS (USA) & $=\mathbf{0 . 9 1 2}$ & ICV (Poland) & $=\mathbf{6 . 6 3 0}$ \\
Impact Factor: & ISI (Dubai, UAE) $=\mathbf{0 . 8 2 9}$ & PUHЦ (Russia) $=\mathbf{0 . 1 5 6}$ & PIF (India) & $=\mathbf{1 . 9 4 0}$ \\
& GIF (Australia) & $=\mathbf{0 . 5 6 4}$ & ESJI (KZ) & $=4.102$ & IBI (India) & $=\mathbf{4 . 2 6 0}$ \\
& JIF & $=\mathbf{1 . 5 0 0}$ & SJIF (Morocco) $=\mathbf{2 . 0 3 1}$ & & \\
\hline
\end{tabular}

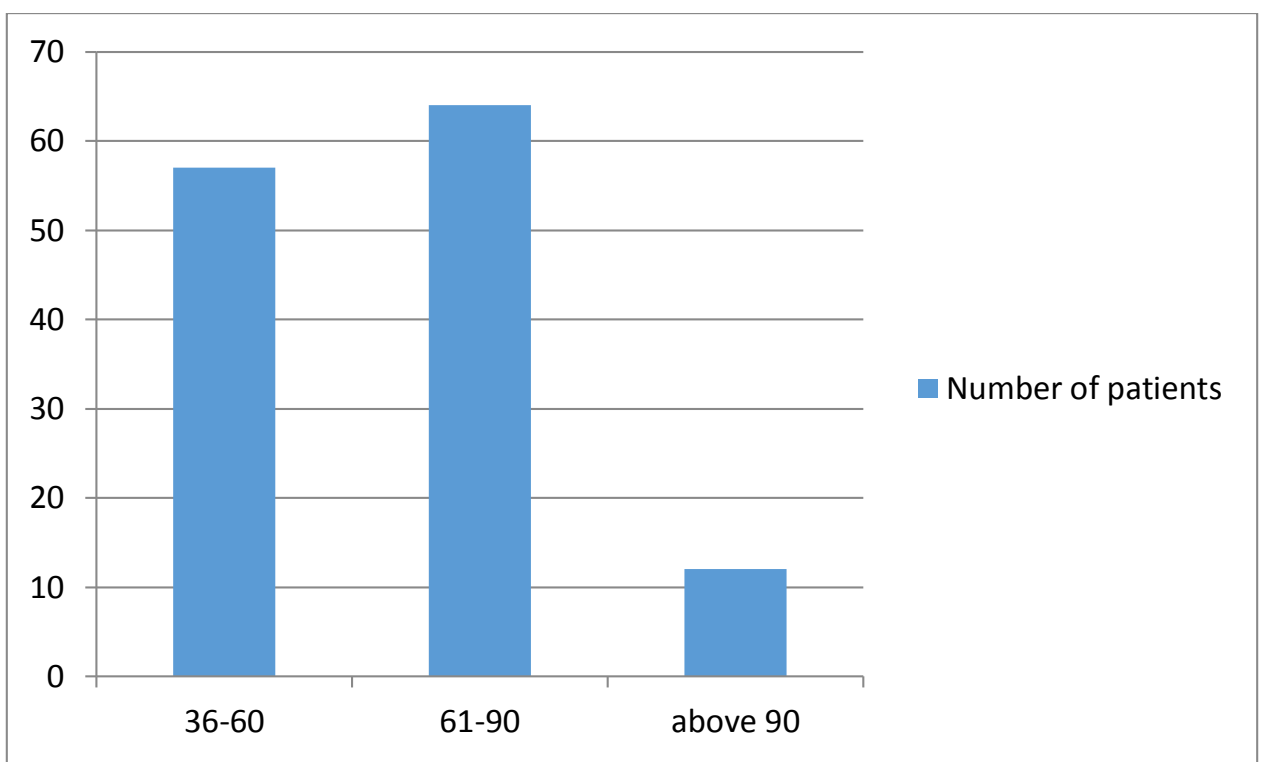

Figure-3 Frequency of cases with prolonged APTT (above $35 \mathrm{sec}$ )

Age distribution among cases of study group

\begin{tabular}{|c|c|c|}
\hline Age of patients (years) & Number of patients & \% \\
\hline $30-35$ & 12 & 8 \\
\hline $36-40$ & 28 & 18.7 \\
\hline $41-45$ & 20 & 13.3 \\
\hline $46-50$ & 18 & 12 \\
\hline $51-55$ & 32 & 21.3 \\
\hline $56-60$ & 15 & 10 \\
\hline Above 60 & 25 & 16.7 \\
\hline
\end{tabular}

Frequency of signs and symptoms of CLD among the patients in study group

Table-2

\begin{tabular}{|c|c|c|}
\hline Sign and symptoms of CLD & Number of patients & \% \\
\hline & 64 & 42.7 \\
\hline Hematemesis & 95 & 63.3 \\
\hline Fever & 73 & 48.7 \\
\hline Jaundice & 91 & 60.7 \\
\hline Hepatomegaly & 38 & 25.3 \\
\hline Splenomegaly & 104 & 69.3 \\
\hline Ascites & 85 & 56.7 \\
\hline Spider angioma & 12 & 8 \\
\hline Encephalopathy & 47 & 31.3 \\
\hline
\end{tabular}




\section{DISCUSSION}

Chronic Liver disease due to viral viral hepatitis has high prevalence in Pakistan and most commonly involving males than females. ${ }^{7}$ Old age people are mostly involved as compared to young age people. There are many other causes of CLD but viral hepatitis is most common reason in Asian countries. ${ }^{8-}$ ${ }^{10}$ In this disease hematological abnormalities are one of many complications in which prothrombin time and APTT is raised, Platelet count is decreased as well. . In this disease protein synthesis is impaired. Albumin is very important protein synthesized by liver maintaining oncotic pressure intravascularly. Its level is also used to diagnose liver failure and to monitor prognosis of disease and outcome of treatment. Normal value of prothrombin time is 1113.5 which is prolonged greater than 14 in liver disease. In severely ill cases its value becomes greater than 45 . Vitamin $\mathrm{K}$ dependent clotting factors 2, 7, 9 and 10 factor synthesis occurs in liver. Liver failure causes impaired vitamin metabolism so decreasing level of clotting factors. ${ }^{11,12}$ Prognostic factors in CLD are blood albumin level, PT and APTT level, platelet count and fibrinogen level. Patients with deranged coagulation profile and low albumin level have worst prognosis. Medical management includes intravenous albumin transfusion, vit $\mathrm{K}$, sandostatin and intravenous fluids etc. ${ }^{13-15}$ This is a cross sectional study conducted in a teaching hospital of Pakistan with study duration of seven months. Patients with chronic liver disease with deranged coagulation profile and signs and symptoms of gastrointestinal bleeding presenting to outpatient door or emergency ward of study institution during study period were selected. Proper history taken and physical examination was done followed by necessary investigations such as USG abdomen, clotting profile (PT, APTT, INR), CBC with platelet count, LFTs, RFTs and stool culture for occult blood or malena. All necessary investigations of study cases were done from the laboratory of study institution. Patients presenting in outpatient door and emergency ward due ti signs and symptoms of chronic liver disease were studied. Total 280 cases reported with chronic liver disease out of which 150 cases were having gastrointestinal bleeding having history of malena and hematemesis. There were $76.7 \%$ cases with prolonged prothrombin time. In $88.6 \%$ cases APTT was prolonged. $86(57.3 \%)$ were having low platelet count less than $1.5 \times 10^{5}$, $10(11.6 \%)$ cases had platelet level between 1-1.5 $\times 10^{5}, 59(68.6 \%)$ cases had platelet range of fifty thousand to one lac and $17(19.7 \%)$ cases had platelet count below fifty thousand. Proper written consent was taken from each and every patient for including their data in study and also from the medical superintendant of the hospital for conducting study. Privacy of patients was maintained. A performa was designed containing necessary questions like age, duration of disease, signs and symptoms of CLD such as ascites, hematemesis, per rectal bleeding, malena etc. ${ }^{16-17}$ Data was analyzed on Microsoft office and statistical software. Relative risk was calculated with $95 \%$ confidence interval. . In severely ill cases its value becomes greater than 45 . Vitamin $\mathrm{K}$ dependent clotting factors 2, 7, 9 and 10 factor synthesis occurs in liver. Liver failure causes impaired vitamin metabolism so decreasing level of clotting factors. Prognostic factors in CLD are blood albumin level, PT and APTT level, platelet count and fibrinogen level. Patients with deranged coagulation profile and low albumin level have worst prognosis. According a study done in Rawalpindi military hospital reported hepatitis $\mathrm{B}$ and $\mathrm{C}$ as a cause in majority of cases (86\%) with CLD.

\section{CONCLUSION}

Chronic liver disease is very common in Pakistan and most common cause is viral hepatitis. There are many complications of this disease but coagulation abnormalities are most important of them which may lead to fatal hemorrhage. In such cases prothrombin time and activated partial thromboplastin time both are prolonged. Thrombocytopenia is also found in majority of these cases. These factors show bad prognosis of the disease.

\section{References:}

1. Amitrano L, Guardascione MA, Brancaccio V, Balzano A. (2002) Coagulation disorders in liver disease. Semin Liver Dis 2002; 22: 83-96.

2. (2007) Peck Radosavljevic M. Review article: coagulation disorders in chronic liver disease.
Aliment Pharmacol Ther 2007; 26 Suppl 1: 218.

3. Rverter JC. (2006) Abnormal hemostasis tests and bleeding in chronic liver disease: are they related? Yes. J Thromb heamost 2006; 4: 71720. 


\begin{tabular}{l|lr|ll|ll} 
& ISRA (India) & $=\mathbf{1 . 3 4 4}$ & SIS (USA) & $=\mathbf{0 . 9 1 2}$ & ICV (Poland) & $=\mathbf{6 . 6 3 0}$ \\
Impact Factor: & ISI (Dubai, UAE) $=\mathbf{0 . 8 2 9}$ & PUHЦ (Russia) $=\mathbf{0 . 1 5 6}$ & PIF (India) & $=\mathbf{1 . 9 4 0}$ \\
& GIF (Australia) & $\mathbf{0 . 5 6 4}$ & ESJI (KZ) & $=4.102$ & IBI (India) & $=\mathbf{4 . 2 6 0}$ \\
& JIF & $=\mathbf{1 . 5 0 0}$ & SJIF (Morocco) & $=2.031$ & & \\
\hline
\end{tabular}

4. Tripodi A. (2009) Tests of coagulation in liver disease. Clin Liver Dis 2009; 13: 55-61.

5. Thachil J. (2008) Relevance of clotting tests in liver disease. Postgrad Med J 2008; 84: 177-81.

6. Pugh RN, Murray-Lyon IM, Dawson JL, Pietroni MC, Williams R. (1973) Transection of the oesophagus for bleeding oesophageal varices. Br J Surg 1973; 60: 649-9.

7. Formen LM, Lucey MR. (2001) Predicting the prognosis of chronic liver disease: an evolution from child to MELD. Mayo end-stage liver disease. Hepatology 2001; 33: 473-5.

8. Garrison RN, Cryer HM, Howard DA, Polk HC. (1984) Clarification of risk factor for abdominal operations in patients with hepatic cirrhosis. Ann Surg 1984; 199: 648-55.

9. Hedner U, Erhardtsen E. (2003) Hemostatic disorders in liver disease. In: Schiff ER, Sorrell MF, Maddrey WC, editors. Diseases of the liver. Philadelphia: Lippincott Williams and Wilkins; 2003; p. 625-35.

10. Lechner K, Niessner H, Thaler E. (1977) Coagulation abnormalities in liver disease. Semin Thromb Hemost 1977; 4: 40-56.

11. Bashour FN, Teran JC, Mullen KD. (2000) Prevalence of peripheral blood cytopenias (hypersplenism) in patients with non-alcoholic chronic liver disease. Am J Gastroenterol 2000; 95: 2936-9.
12. Schepis F, Camma C, Niceforo D, Magnano A, Pallio S, Cinquegrani M, et al. (2001) Which patients with cirrhotic should undergo endoscopic screening for esophageal varices detection? Hepatology 2001; 33: 333-8

13. Zaman A, Hapke R, Flora K, Rosen HR, Benner K. (1999) Factors predicting the presence of esophageal or gastric varices in patients with advanced liver disease. Am J Gastroenterol 1999; 94: 3292-6.

14. (2008) Clinical and Laboratory Standards Institute (CLSI). Collection, transport and processing of blood specimens for testing plasma-based coagulation assays and molecular hemostasis assays; approved guideline. 5th ed.H21-A5. Pennsylvania USA; 2008.

15. (2001) Clinical and Laboratory Standards Institute (CLSI). Procedure for the Determination of Fibrinogen in Plasma; Approved Guideline.2nd ed.H30A2.Pennsylvania, USA; 2001.

16. Bukhtiari N, Hussain T, Iqbal M, Malik AM, Qureshi AH, Hussain A. (2003) Hepatits B and $\mathrm{C}$ single and co-infection in Chronic liver disease and their effect on the disease pattern. $\mathrm{J}$ Pak Med Assoc 2003; 53: 136-40.

17. Nidegger D, Ragot S, Berthelemy P, Masliah C, Pilette C, Martin T, et al. (2018) Cirrhosis and bleeding: the need for very earlymanagement. J 